\title{
Evaluation of antidepressant activity of hydro-alcoholic extract of rhizomes of Nardostachys jatamansi DC per se and in combination with fluoxetine in wistar albino rats and swiss albino mice
}

\author{
Radhika Panchal, Nutanbala N. Goswami*, Ashish Anovadiya
}

Department of Pharmacology, Government Medical College, Bhavnagar, Gujarat, India

Received: 24 November 2019

Revised: 18 December 2019

Accepted: 19 December 2019

\section{*Correspondence:}

Dr. Nutanbala N. Goswami,

Email: drnutangoswami78@gmail.com

Copyright: (C) the author(s), publisher and licensee Medip Academy. This is an open-access article distributed under the terms of the Creative Commons Attribution Non-Commercial License, which permits unrestricted non-commercial use, distribution, and reproduction in any medium, provided the original work is properly cited.

\begin{abstract}
Background: Depression is a common mental disorder results due to deficiency of neurotransmitter in the brain. Various medicinal properties of jatamansi are mentioned in Ayurveda. This study evaluated effect of hydro-alcoholic extract of rhizomes of Nordostachys jatamansi DC per se and in combination with fluoxetine in wistar albino rats and swiss albino mice.

Methods: Animals of either sex were selected and randomly divided in test group. Jatamansi extract 10:1 and fluoxetine hydrochloride dissolved in distilled water were used. Animals were tested for forced swimming test, tail suspension test and locomotor after given test drug. Results were compared with control and analysed.

Results: Nardostachys jatamansi DC, when given to rats showed dose dependent increase in number of rotation during forced swimming test in rats. During forced swimming test in glass jar statistically significant decrease in immobility was observed. Nardostachys jatamansi DC, when given to mice dose dependent statistically significant decrease in immobility time, swimming time and climbing observed. When given along with combination of fluoxetine it shows statistically significant difference in result, confirmed that it can have synergistic antidepressant activity. When used for locomotor activity in mice none of the test drugs significantly increase or decrease the locomotor activity.

Conclusions: Jatamansi showed antidepressant like property in various tests conducted on rats and mice. It showed statistically significant result with increasing dose and had synergic effect when given along with fluoxetine.
\end{abstract}

Keywords: Forced swim test, Tail suspension test, Depression, Jatamansi

\section{INTRODUCTION}

Depression is a common mental disorder, characterized by sadness, loss of interest or pleasure, feeling of guilt or low self- worth, disturbed sleep or appetite, feeling of tiredness and poor concentration. ${ }^{1}$ Reports on global burden of disease estimates the point prevalence of unipolar depressive episodes to be $1.9 \%$ for men and $3.2 \%$ for women. ${ }^{2}$ Major depression is a common debilitating disorder affecting $10 \%-15 \%$ of the population per year. Only 60-70\% of patients with depression respond to antidepressant therapy. Of those who do not respond, $10-30 \%$ exhibit treatment-resistant symptoms coupled with difficulties in social and occupational function, decline of physical health, suicidal thoughts, and increased health care utilization. Treatment-resistant depression represents a dilemma for health care providers. ${ }^{3}$ Selective serotonin reuptake inhibitors acts by initially blocking reuptake and results in enhanced and prolonged serotonergic neurotransmission. ${ }^{4}$ Herbal 
preparation provides new insight for the treatment of depression. Many herbal preparations are proven to possess antidepressant activity. ${ }^{4}$

Nordostachys jatamansi also called nard, nardin spikenard and muskroot is flowering plants of the valerian family that groves in Nepal, China and India. Various medicinal properties of jatamansi are mentioned in Ayurveda. ${ }^{5}$ Hence, the present study was planned to evaluate the antidepressant like activity of hydroalcoholic extract of rhizomes of Nardostachys jatamansi DC and to see its effect as add on therapy to commonly prescribed antidepressants in clinical practice.

\section{METHODS}

The study was conducted at the laboratory of the department of Pharmacology, Government Medical College, Bhavnagar after institutional animal ethical committee approval (IAEC No. 46/2016, dated $25^{\text {th }}$ June 2016). The animal handling was performed according to guidelines of the committee for purpose of control and supervision of experiments on animals, New Delhi.

Swiss albino mice of 3-4 months of age of either sex weighing 24-30 grams were used in this study conducted during period from July 2016 to May 2017. All the animals were acclimatized to the laboratory conditions at least one day prior to the experiments. Food was withdrawn 12 hours before the experiments. Each animal was used only once. Jatamansi extract 10:1 and Fluoxetine hydrochloride dissolved in distilled water were used in the study. Dose of jatamansi was calculated by using data from other medical literature, considering the median dose of $200 \mathrm{mg} / \mathrm{kg}$ and $400 \mathrm{mg} / \mathrm{kg}$ were taken as low dose and high dose respectively. Fluoxetine hydrochloride dose used for swimming test $14 \mathrm{mg} / \mathrm{kg}$ for rats, $20 \mathrm{mg} / \mathrm{kg}$ for mice, for tail suspension test and locomotor activity in mice $20 \mathrm{mg} / \mathrm{kg}$. 5,6

Forced swimming test apparatus with activity wheel was used for swimming test for rat, borosilicate glass cylinder was used for forced swimming test for rat and mice. Forced swimming test with activity wheel was performed as described by Nomura et al and Can et al. ${ }^{7,8}$ Forced swimming test in glass jar was performed as described by Porsolt et al. ${ }^{9}$ Tail suspension test assembly used for tail suspension test in mice. Tail suspension test was done as described by Steru et al. ${ }^{10}$ For measurement of locomotor activity in mice digital photoactometer was used as described in study of Tatem et al. ${ }^{11}$

Animals were grouped with each group having six animals. Group 1 was found vehicle control group, (distilled water), Group 2 was given Nardostachys jatamansi low dose, Group 3 was given Nardostachys jatamansi high dose, Group 4 was given fluoxetine hydrochloride; Group 5 was given fluoxetine hydrochloride and Nardostachys jatamansi. In rats, for all the group of animals, vehicle and test drugs were administered orally for 14 days. After 60 minutes of administration on $14^{\text {th }}$ day number of rotation in water wheel conducted. In mice for all the group of animals, vehicle and test drugs were administered orally for 24 hours, 5 hours and 1 hour before the test. Period of immobility, swimming and climbing was then digitally recorded by camera and then analyzed. Statistical analysis of data was carried out by one way ANOVA followed by Tuckey-Kramer multiple comparison test.

\section{RESULTS}

In Table 1, test group showed significant increase in number of rotations in forced swimming test in rats with fluoxetine $(\mathrm{p}<0.01)$, jatamansi high as well as low dose $(\mathrm{p}<0.01)$ and combination of fluoxetine with jatamansi $(\mathrm{p}<0.05)$

Table 1: Effect of test drugs on number of rotation in forced swimming test with activity wheel in rats $(n=6$ in each group).

\begin{tabular}{|llll|}
\hline Group & Treatment & Dose & $\begin{array}{l}\text { No. of } \\
\text { rotations } \\
\text { (Mean } \pm \text { SEM) }\end{array}$ \\
\hline $\mathbf{1}$ & Vehicle control & $2.5 \mathrm{ml}$ & $10.6 \pm 0.5$ \\
\hline $\mathbf{3}$ & Fluoxetine & $14 \mathrm{mg}$ & $28.5 \pm 0.7$ \\
\hline $\mathbf{4}$ & Jatamansi & $125 \mathrm{mg}$ & $34.1 \pm 0.9$ \\
\hline $\mathbf{5}$ & Jatamansi & $320 \mathrm{mg}$ & $55.0 \pm 1.1$ \\
\hline & Fluoxetine and & $14 \mathrm{mg}$ and & $76.1 \pm 1.4$ \\
\hline
\end{tabular}

Forced swimming test performed for rats using glass jar showed statistically significant decrease in immobility in test group rats with fluoxetine $(\mathrm{p}<0.01)$, jatamansi high as well dose $(p<0.01)$ and combination of fluoxetine with jatamansi $(\mathrm{p}<0.05)$.

Table 2: Effect of test drugs on immobility, swimming and climbing time in forced/swimming test in mice (n=6 in each group).

\begin{tabular}{|llllll|}
\hline Group & Treatment & Dose & $\begin{array}{l}\text { Immobility time } \\
(\mathrm{sec}) \text { Mean } \pm \text { SEM }\end{array}$ & $\begin{array}{l}\text { Swimming time } \\
(\mathrm{sec}) \text { Mean } \pm \text { SEM }\end{array}$ & $\begin{array}{l}\text { Climbing time } \\
\text { (sec) Mean } \pm \text { SEM }\end{array}$ \\
\hline $\mathbf{1}$ & Vehicle control & $2.5 \mathrm{ml}$ & $220.3 \pm 5.8$ & $51.3 \pm 5.7$ & $29.6 \pm 4.0$ \\
\hline $\mathbf{2}$ & Fluoetine & $14 \mathrm{mg}$ & $94.0 \pm 4.2$ & $137.1 \pm 9.3$ & $68.8 \pm 8.0$ \\
\hline $\mathbf{3}$ & Jatamansi & $200 \mathrm{mg}$ & $100.0 \pm 4.7$ & $73.6 \pm 6.1$ & $90.3 \pm 7.2$ \\
\hline $\mathbf{4}$ & Jatamansi & $400 \mathrm{mg}$ & $141.6 \pm 8.6$ & $124.5 \pm 9.1$ & $75.2 \pm 5.6$ \\
\hline $\mathbf{5}$ & Fluoetine and jatamansi & $14 \mathrm{mg}$ and $400 \mathrm{mg}$ & $41.5 \pm 7.8$ & $155.6 \pm 5.0$ & $102.8 \pm 6.0$ \\
\hline
\end{tabular}


Table 2 showing statistically significant decrease in immobility time, swimming time and climbing time in mice treated with fluoxetine $(\mathrm{p}<0.01)$, jatamansi high as well as low dose $(\mathrm{p}<0.01)$ and combination of Fluoxetine with jatamansi $(\mathrm{p}<0.05)$

Table 3: Effect of test drugs on time of immobility in tail suspension test in mice ( $n=6$ in each group).

\begin{tabular}{|llll|}
\hline Group & Treatment & Dose & $\begin{array}{l}\text { Immobility } \\
\text { time }(\mathrm{sec}) \\
\text { Mean } \pm \text { SEM }\end{array}$ \\
\hline $\mathbf{1}$ & Vehicle control & $2.5 \mathrm{ml}$ & $172.0 \pm 7.1$ \\
\hline $\mathbf{2}$ & Fluoetine & $20 \mathrm{mg}$ & $36.6 \pm 3.7$ \\
\hline $\mathbf{3}$ & Jatamansi & $200 \mathrm{mg}$ & $94.0 \pm 4.0$ \\
\hline $\mathbf{4}$ & Jatamansi & $400 \mathrm{mg}$ & $61.8 \pm 1.9$ \\
\hline $\mathbf{5}$ & Fluoetine and & $20 \mathrm{mg}$ and & $21.3 \pm 5.4$ \\
\hline
\end{tabular}

As shown in Table 3, during tail suspension test performed in mice time of immobility is significantly reduced in treatment group jatamansi alone $(\mathrm{p}<0.05)$ as well as with fluoxetine and jatamansi combination $(\mathrm{p}<0.001)$.

Table 4: Effect of test drugs on locomotor activity in photoactometer in mice ( $n=6$ in each group).

\begin{tabular}{|llll|}
\hline $\begin{array}{l}\text { Group } \\
\text { no. }\end{array}$ & $\begin{array}{l}\text { Treatment } \\
\text { groups }\end{array}$ & Dose & $\begin{array}{l}\text { Total count } \\
(\mathrm{sec}) \\
\text { Mean } \pm \text { SEM }\end{array}$ \\
\hline $\mathbf{1}$ & Vehicle control & $2.5 \mathrm{ml}$ & $118.3 \pm 10.2$ \\
\hline $\mathbf{2}$ & Fluoetine & $20 \mathrm{mg}$ & $121.0 \pm 18.9$ \\
\hline $\mathbf{3}$ & Jatamansi & $200 \mathrm{mg}$ & $120.6 \pm 16.5$ \\
\hline $\mathbf{4}$ & Jatamansi & $400 \mathrm{mg}$ & $123.0 \pm 14.0$ \\
\hline $\mathbf{5}$ & $\begin{array}{l}\text { Fluoetine and } \\
\text { jatamansi }\end{array}$ & $\begin{array}{l}20 \mathrm{mg} \text { and } \\
400 \mathrm{mg}\end{array}$ & $111.0 \pm 13.8$ \\
\hline
\end{tabular}

Table 4 showed result of locomotor activity of mice using digital photoactometer. There was not any statistical significance found among any of the groups. None of the test drugs significantly increase or decrease the locomotor activity.

\section{DISCUSSION}

Depression is one of the most common mental disorders with increasing incidence worldwide requiring utmost attention in treatment and research. Although many antidepressant drugs are available in the market but due to their anticipated adverse effects at the therapeutic doses such as insomnia, dizziness, weight gain, convulsions, cardiac arrthymias, postural hypotension, anticholinergic symptoms search for new better tolerated and more efficacious antidepressants with benign profile of adverse drug reactions still continues. ${ }^{12}$ Various paradigms have been developed which are instrumentals (objective) in detecting antidepressant potential of novel compounds in preclinical set up. ${ }^{13}$ In present study both acute and chronic model with two different species of animals (wistar albino rats) and (swiss albino mice) used as each have its own peculiarities. The rats seem to be more selective and mice are more sensitive model.

Nardostachys jatamansi DC, when given to rats as monotherapy in dose of $125 \mathrm{mg} / \mathrm{kg}$ and $300 \mathrm{mg} / \mathrm{kg}$ showed dose dependent increase in number of rotation during forced swimming test in rats. During forced swimming test in glass jar statistically significant decrease in immobility was observed. Nardostachys jatamansi DC, when given to mice dose dependent statistically significant decrease in immobility time, swimming time and climbing was observed. When given along with combination of fluoxetine it shows statistically significant difference in result, confirmed that it can have synergistic antidepressant activity. When used for locomotor activity in mice none of the test drugs significantly increase or decrease the locomotor activity, confirms that assumption that the antidepressant like effect of jatamansi is specific and not false positive.

Rahman et al in his study concluded that methanolic extract of Nardostachys jatamansi DC, has dose dependent antidepressant activity and can also be used in patients suffering from depression due to sleep disturbances which also improve the locomotor activity in sleep deprived mice. ${ }^{6}$ So, Nardostachys jatamansi DC will be an important plant to carry research for antidepressant activity and can be a drug of choice for people who suffer from acute sleep deprivation. In study of Deepa et al, the electron beam radiated mice treated with Nardostachys jatamansi ethanolic root extract has shown a significant reduction in the duration of immobility (in seconds) in both the tests on comparing with non-treated electron beam radiated mice. ${ }^{14}$ Dhingra et al observed ethanolic extract $(100,200$ and $400 \mathrm{mg} / \mathrm{kg}$, po) of Nardostachys jatamansi administered for 14 successive days to swiss young albino mice (either sex) produced significant antidepressant-like effect in both tail suspension and forced swim tests. ${ }^{15}$ The efficacy of the extract was found to be comparable to imipramine (15 $\mathrm{mg} / \mathrm{kg}$, po) and sertraline (20 mg/kg, po). Ethanolic extract $(200 \mathrm{mg} / \mathrm{kg}$, po) did not show any significant change on locomotor activity of mice as compared to control; hence it did not produce any motor effects.

\section{CONCLUSION}

In the systems of traditional medicine, numerous plants and formulations have been used to take care of depression for thousands of years. We have reported antidepressant activity of jatamansi. In our study jatamansi showed antidepressant like property in various tests conducted on rats and mice. It showed statistically significant result with increasing dose and had synergic effect when given along with fluoxetine. We recommend further research elucidate the mechanism of action involved in the antidepressant activity of jatamansi. There are number of medicinal plants and formulation that 
possess antidepressant activity comparable to clinically effective synthetic antidepressants. Thus, plants based formulations can be effectively used for the treatment of mild to moderate cases of depression.

\section{ACKNOWLEDGEMENTS}

The authors are thankful to Kuber Impex, Indore for supplying jatamansi extract and Sun Pharmaceuticals Ltd for supplying fluoxetine. We are also thankful to animals used for study.

Funding: No funding sources

Conflict of interest: None declared

Ethical approval: The study was approved by the Institutional Ethics Committee

\section{REFERENCES}

1. WHO. Risks to mental health: An overview of vulnerabilities and risk factors. J Psychiatr Res. 2012: $1-14$.

2. Cheung IWY, Nakayama S, Hsu MNK, Samaranayaka AGP, Li-Chan ECY. Angiotensin -I converting enzyme inhibitory activity of hydrolysates from oat protein by in silino and vitro analysis. J Agric Food chem. 2009;57(19):234-42.

3. Souery D, Amsterdam J, deMontigny C, Lecrubier Y, Montgomery S, Lipp O, et al. Treatment resistant depression: methodological overview and operational criteria. Eur Neuropsychopharmacol. 1999;9:83-91.

4. Lee G, Bae H. Therapeutic effects of Phytochemicals and Medicinal Herbs in Depression. Biomed Res Int. 2010;6(3):205-12

5. Sahu R, Dhongade HJ, Pandey A, Sahu P, Patel D. Medicinal properties of Nardostachys Jatamansi. Oriental J Chem. 2016;32(2):859-66

6. Rahman H, Muralidharan P. Comparative study of antidepressant activity of methanolic extract of Nardostachys Jatamansi DC Rhizome on normal and sleep deprived mice. Scholars Res Library Der Pharmacia Lettre. 2010;2(5):441-9.
7. Nomura S, Shimizu J, Kinjo M, Kametani H, Nakazawa T. A new behavioral test for antidepressant drugs. Eur J Pharmacol. 1982;83(34):171-5.

8. Can A, Dao DT, Arad M, Terrillion CE, Piantadosi SC, Gould TD. The Mouse Forced Swim Test. J Vis Exp. 2012;59:3638.

9. Porsolt RD, Anton G, Blavet N, Jalfre M.Behavioural despair in rats: a new model sensitive to antidepressant treatments. Eur J Pharmacol. 1978;47(4):379-91.

10. Steru L, Chermat R, Thierry B, Simon P.The tail suspension test: a new method for screening antidepressants in mice. Psychopharmacology (Berl). 1985;85(3):367-70.

11. Tatem KS, Quinn JL, Phadke A, Yu Q, GordishDressman H, Nagaraju K. Behavioral and Locomotor Measurements Using an Open Field Activity Monitoring System for Skeletal Muscle Diseases. J Vis Exp. 2014;91:51785.

12. Tripathi KD. Drug used in mental illness. Chapter 33, Essential of Medical Pharmacology, 8th edition. Jaypee Brothers Medical publishers; 2016.

13. Vogel HG, Vogel WH. Drug discovery and evaluation: Pharmacological assays. Springer Sci Business Media; 2013.

14. Deepa B, Suchetha K, Rao S. Antidepressant activity of nardostachys jatamansi in electron beam irradiated mice. Int J Res Ayurveda Pharmacy. 2013;4(1):1013.

15. Dhingra D, Goyal PK. Inhibition of MAO and GABA: probable mechanisms for antidepressant-like activity of Nardostachys jatamansi DC. in mice. Indian J Exp Biol. 2008;46(4):212-8.

Cite this article as: Panchal R, Goswami NN, Anovadiya A. Evaluation of antidepressant activity of hydro-alcoholic extract of rhizomes of Nardostachys jatamansi DC per se and in combination with fluoxetine in wistar albino rats and swiss albino mice. Int J Basic Clin Pharmacol 2020;9:32-5. 